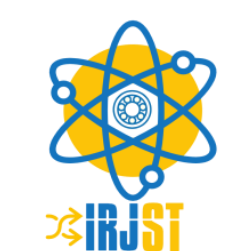

Available online at https://www.irjst.com/

International Research Journal of Science and Technology

ISSN: 2707-3955

DOI: https://doi.org/10.46378/irjst.2020.010401

\title{
Demonstration of Common Bean Varieties (Dursitu and Chercher) in the Gurawa and Kurfa Chele Districts, East Hararghe Zone, Oromia Region, Ethiopia.
}

\author{
Suleyman Abdureman Omer ${ }^{1 *}$ and Nuradin Abdi Hassen ${ }^{2}$ \\ ${ }^{1}$ Researcher, Research Facilities, Haramaya University, Ethiopia. \\ ${ }^{2}$ Lecturer \& Researcher, Rural Development and Agricultural Extension Department, Haramaya University, Ethiopia.
}

\begin{tabular}{llll}
\multicolumn{2}{ll}{ Paper Status } & & \\
Received : & & Aug & 2020 \\
Accepted & $:$ & Sep & 2020 \\
Published $:$ & Sep & 2020
\end{tabular}

Key Words

Demonstration

Field days

Improved Common Beans

Training

\begin{abstract}
Common bean is becoming increasingly important in eastern Ethiopia because of the recurrent late-onset and early termination of rainfall. It is an important crop under various intercropping systems. The major problems of common bean production in Eastern Ethiopia are inaccessibility to improved common bean varieties, low extension intervention, and inferior performance of local varieties. Hence, its specific objectives were to demonstrate the two improved common bean varieties (Dursitu and Chercher) with the local one; to evaluate their performances and identify a variety that meets farmers' criteria. Gurawa and Kurfa Chele districts were identified from Eastern Hararghe Zone using purposive sampling technique based on common bean production potential. Two kebeles were identified from each district. Three model farmers were selected from each kebele depending on common bean production potential. Training is one of the important extension methods to enhance and integrate the farmers' indigenous knowledge and skill with improved practices. Field days were organized in June for Belg and September for the Maher seasons. The common beans were compared and prioritized based on participants' criteria. Chercher variety was selected first, Dursitu second and the local common bean third based on their maturity dates, colour and market demand. In general, participants' capability and skill on the improved common bean production technologies increased. The ground for further popularization and dissemination of the two improved common bean technologies was established.
\end{abstract}

Copyright (C) 2020: Suleyman Abdureman Omer and Nuradin Abdi Hassen. This is an open-access distribution, and reproduction in any medium provided Access article distributed under the Creative Commons Attribution License the original work is properly cited License, which permits unrestricted use.

Citation: Suleyman Abdureman Omer and Nuradin Abdi Hassen. "Demonstration of Common Bean Varieties (Dursitu and Chercher) in the Gurawa and Kurfa Chele Districts, East Hararghe Zone, Oromia Region, Ethiopia”. International Research Journal of Science and Technology, 1 (4), 272-276, 2020.

\section{Introduction}

Common bean is becoming increasingly important in eastern Ethiopia because of the recurrent late-onset and early termination of rainfall, which force the farmers to use short-duration crops. It is an important component of crop production in Hararghe under various intercropping systems. It is used as soil fertility management, as emergency and security crop and as a supplemental animal feed ([1] [2].

\footnotetext{
* Corresponding Author: Suleyman Abdureman Omer

Researcher, Research Facilities, Haramaya University, Ethiopia Email: suleymanabdureman65@gmail.com
}

The major problems of common bean production in Eastern Ethiopia are inaccessibility to improved common bean varieties, low extension intervention, and inferior performance of local varieties.

To address these constraints, Haramaya University (HU) developed eleven improved common bean varieties along with its improved practices during the last 10-15 years, of which eleven are food beans (Gofta, Ayenew, Haramaya, Dursitu and Kufanzik, Tinike, Hirna, Babile, Fedis, Hundane and one navy (white) variety (Chercher). The merits of the new varieties include high yield (17-40 qts/ha on research 
stations and 13-21qts/ha on-farmers' field), tolerant to major diseases, excellent growth habit, early maturing (82-114 days) and adaptive to wider agroecology of 1300-2000 m.a.s.1. [1] [2][3].

Most of the technologies developed were not demonstrated and transferred to the end-users through appropriate extension methods to complement the work conducted on research stations, and to provide a more realistic evaluation of the new technology under farmers' condition. The process also provides an excellent opportunity for farmers to learn, evaluate, and participate in the recommendations drawn on the specific technology. Furthermore, it can encourage and strengthen researchers - extension - farmers stakeholders and policymakers' dialogue and provide an opportunity to jointly identify research thematic area, participatory technology generation, transfer and utilization. Hence, the objective of this project was to demonstrate the two recently released common bean varieties (Dursitu and Chercher) with the local one in Gurawa and Kurfa Chele districts during Belg and Maher to select the variety (ies) that meet farmers' criteria and thereby increase target farmers common bean production from 10.5- $21 \mathrm{qts} / \mathrm{ha}$.

\section{Material \& Research Methods}

\subsection{Description of the Study Area}

Eastern Hararghe Districts (kurfa chele and Gurawa) are situated at an altitude of 1357-3200 m.a.s.l. Their annual rainfall ranges from 500 to $1200 \mathrm{~mm}$. They have bimodal rainfall distribution, the small rainy season which occurs in February and the main rainy season that occur between June and September. The major crops grown in the districts are sorghum, maize, teff and haricot beans, groundnut, coffee and chat. Eastern Hararghe farmers grow common bean twice per year (during Belg and Maher especially in Gurawa). The Belg production is sol and larger, whereas Maher is mostly intercropping with various major crops. They usually sow teff after the harvest of Belg on the common bean fields in Gurawa.

\subsection{Sampling Technique}

Gurawa and Kurfa Chele districts were identified from Eastern Hararghe Zone using purposive sampling technique based on common bean production potential. Two kebeles were identified from each district. Three model farmers were selected from each kebele depending on common bean production potential, full interest to participate in the project during the two seasons (Belg \& or Maher), ability to allocate the required land for the three common bean varieties (two improved and one local variety). The name of the target farmers, their respective districts and peasant associations (PAs) is indicated in Tables 6.3 and 6.4.

\subsection{Training}

Training is one of the important extension methods to enhance and integrate the farmers' indigenous knowledge and skill with improved practices. Accordingly, training need assessment before and after technology demonstration was made. Six development agents (4 in Gurawa and 2 in kurfa chele districts), 2 district extension experts one from each district, and 12 target farmers ( 6 from Gurawa and 6 from kurfa chele districts) attended the training on the common beans agronomic practices before sowing (Tables 6.1 and 6.2). Each target farmer provided $10 \mathrm{mx} 20 \mathrm{~m}$ of land for the two improved common beans and one local common bean varieties demonstration in Belg and Maher. Necessary packages were distributed together with the varieties. The varieties were sown in April for Belg and in late July for Maher because of the late onset of rainfall in both seasons. Field days were organized in June for Belg and September for the Maher seasons. The performance of each improved common bean varieties was evaluated against the local check-in each kebele in terms of their yield performances, diseases tolerance, maturity dates and market demand (Tables 6.3, 6.4, 6.5 and 6.6).

\section{Result and Discussion}

Table 6.1 shows that target farmers' knowledge and skill on improved common bean agronomic practices was very low but increased after training.

Table 6.2 shows those development agents' knowledge and skill on improved common bean agronomic practices to be quite low before the training, which was greatly improved after undertaking the training.

\subsection{Farmers Days}

Farmers' days were conducted at flowering stage and at harvesting stage. At the flowering stage, crops resistances to different diseases and drought tolerance ability were evaluated. At the harvesting stage, the yield performances were evaluated (Figure 6.1.). During the Belg season, a total of twelve target farmers, 4 development agents, 2 district extension experts and 55 follower farmers participated in Gurawa and Kurfa chele districts.

\subsection{Evaluation at harvest}

During the Maher season, a total of twelve other target farmers, 2 development agents, 2 districts' extension experts, 63 follower farmers participated at both districts. The common beans were compared and prioritized based on participants' criteria as follows: 
Table 6.1. Training needs assessments before and after training on the target farmers Training Need Assessments

\begin{tabular}{lllllllll}
\hline \multirow{2}{*}{ Questions } & \multicolumn{3}{l}{ Farmers Before Training } & \multicolumn{3}{c}{ Farmers After Training } \\
\cline { 2 - 9 } & $\mathrm{M}$ & $\mathrm{F}$ & Total & $\%$ & $\mathrm{M}$ & $\mathrm{F}$ & Total & $\%$ \\
\hline Land preparation & 3 & - & 12 & 25 & 11 & - & 12 & 91.6 \\
Row planting & - & - & 12 & 0 & 10 & - & 12 & 83.4 \\
Spacing & - & - & 12 & 0 & 10 & - & 12 & 83.4 \\
Weed control & 6 & - & 12 & 50 & 12 & - & 12 & 100 \\
Disease control & - & - & 12 & 0 & 11 & - & 12 & 83.4 \\
Harvesting & 4 & - & 12 & 33.3 & 12 & - & 12 & 100 \\
Post-Harvesting Mgt. & - & - & 12 & 0 & 9 & - & 12 & 75 \\
Crop rotation & 6 & - & 12 & 50 & 12 & - & 12 & 100 \\
Soil fertility & 6 & - & 12 & 50 & 12 & - & 12 & 100 \\
\hline
\end{tabular}

Table 6.2. Training needs assessments before and after training for development agents Training Need Assessments

\begin{tabular}{|c|c|c|c|c|c|c|c|c|}
\hline \multirow{2}{*}{ Questions } & \multicolumn{4}{|c|}{ Farmers Before Training } & \multicolumn{4}{|c|}{ Farmers After Training } \\
\hline & $\mathrm{M}$ & $\mathrm{F}$ & Total & $\%$ & $\mathrm{M}$ & $\mathrm{F}$ & Total & $\%$ \\
\hline Land preparation & 3 & - & 6 & 50 & 6 & - & 6 & 100 \\
\hline Row planting & 2 & - & 6 & 33.3 & 6 & - & 6 & 100 \\
\hline Spacing & 3 & - & 6 & 50 & 6 & - & 6 & 100 \\
\hline Weed control & 4 & - & 6 & 66.7 & 6 & - & 6 & 100 \\
\hline Disease control & 3 & - & 6 & 50 & 6 & - & 6 & 100 \\
\hline Harvesting & 1 & - & 6 & 16,7 & 6 & - & 6 & 100 \\
\hline Post-Harvesting Mgt. & 1 & - & 6 & 16.7 & 6 & - & 6 & 100 \\
\hline Crop rotation & 4 & - & 6 & 66.7 & 6 & & 6 & 100 \\
\hline Soil fertility & 4 & - & 6 & 66.7 & 6 & & 6 & 100 \\
\hline
\end{tabular}

Table 6.3. Name of target farmers, and grain yield of common bean varieties during Belg season in Gurawa and Kurfa chele districts

\begin{tabular}{lllllllll}
\hline \multirow{2}{*}{ Name of Farmers } & \multirow{2}{*}{ District } & \multirow{2}{*}{ PAs } & \multicolumn{7}{l}{ Yield/plot (200m2) in qt. } & \multicolumn{2}{l}{ Yield qt /ha. } \\
\cline { 4 - 8 } & & & Chercher & Dursitu & Local & Chercher & Dursitu & Local \\
\hline Ahemed Sali & Gurawa & G/Gemachu & 0.30 & 0.28 & 0.14 & 15.00 & 14.00 & 7.00 \\
Abdalla Usman & Gurawa & G/Gemachu & 0.36 & 0.20 & 0.12 & 18.00 & 10.00 & 6.00 \\
TeshagerTeshome & Gurawa & G/Gemachu & 0.42 & 0.33 & 0.90 & 21.00 & 16.50 & 4.50 \\
Demisie Belachaw & Gurawa & Bedu & 0.22 & 0.18 & 0.13 & 11.00 & 9.00 & 6.50 \\
\hline Toatal & & & 1.30 & 0.99 & 0.48 & 0.65 & 49.5 & 24.00 \\
\hline Mean & & & 32.5 & 24.75 & 12.00 & 16.3 & 12.40 & 6.00 \\
\hline *Mohamed Amin & Gurawa & Bedu & 0.00 & 0.00 & 0.00 & 0.00 & 0.00 & 0.00 \\
*Eshetu Kinfe & Gurawa & Bedu & 0.00 & 0.00 & 0.00 & 0.00 & 0.00 & 0.00 \\
Abrahim Amed & Kurfa & Dawe & 0.55 & 0.45 & 0.24 & 27.5 & 22.5 & 12.00 \\
Ahemed Hasen & Kurfa & Dawe & 0.30 & 0.16 & 0.15 & 15.00 & 8.00 & 7.50 \\
Miftiha shekrashid & Kurfa & Dawe & 0.50 & 0.34 & 0.18 & 25.00 & 17.00 & 12.50 \\
Miftha Haji & Kurfa & Dawe & 0.37 & 0.22 & 0.13 & 18.50 & 11.00 & 6.50 \\
Alemayehu Kebede & Kurfa & Kerso & 0.22 & 0.17 & 0.11 & 11.00 & 8.5 .00 & 5.50 \\
Debebe Makeshe & Kurfa & Kerso & 0.75 & 0.40 & 0.28 & 37.50 & 20.00 & 14.00 \\
\hline Total & & & 2.34 & 1.74 & 1.09 & 117.0 & 87.00 & 58.00 \\
\hline Mean & & & 0.39 & 0.29 & 0.18 & 19.50 & 14.50 & 9.70 \\
\hline
\end{tabular}

*Indicted that the common bean demonstrations on the two farmers' plots were affected by drought and there was no yield.

Dursitu improved common bean variety was selected first for its grain and biomass yield and Chercher for maturity date and drought resistances during summer in Gurawa district. But Chercher was rated first and Dursitu second in Kurfa chele district in both seasons based on yield performances and earliness in maturity. Dursitu variety needs more time to mature. The target farmers and participants decided to share the available seed they harvested to other follower farmers and also decided to grow the two improved common bean varieties. But, they decided to grow Dursitu common bean only during the main rainy season as it needs an extended period of rain to fetch its full production potential. 
Table 6.4. Name of target farmers, and yield performances of bean varieties in Maher season in Gurawa and Kurfa chele districts

\begin{tabular}{|c|c|c|c|c|c|c|c|c|}
\hline \multirow[t]{2}{*}{ Name of Farmers } & \multirow[t]{2}{*}{ District } & \multirow[t]{2}{*}{ PAs } & \multicolumn{3}{|c|}{$\begin{array}{l}\text { Yield /Plot }\left(200 \mathrm{~m}^{2}\right) \text { in } \\
\text { quintals. }\end{array}$} & \multicolumn{3}{|c|}{ Yield qts/ha. } \\
\hline & & & Chercher & Dursitu & Local & Chercher & Dursitu & Loca \\
\hline Tasfa Demeke & Gurawa & Lafto & 0.30 & 0.35 & 0.17 & 15.00 & 17.50 & 7.50 \\
\hline Hashum Usmael & Gurawa & Lafto & 0.60 & 0.80 & 0.32 & 30.00 & 40.00 & 16.00 \\
\hline $\begin{array}{l}\text { Mohamed } \\
\text { Abrahim }\end{array}$ & Gurawa & Lafto & 0.50 & 0.50 & 0.28 & 25.00 & 25.00 & 14.00 \\
\hline Worku Endrias & Gurawa & Jiru Gamachu & 0.40 & 0.65 & 0.24 & 20.00 & 32.50 & 10.00 \\
\hline Saniyo Ahimed & Gurawa & Jiru Gamachu & 0.34 & 0.60 & 0.18 & 17.00 & 30.00 & 8.50 \\
\hline *Abdella Saniyo & Gurawa & Kufa Kas & 0.00 & 0.00 & 0.00 & 0.00 & 0.00 & 0.00 \\
\hline Total & & & 2.14 & 2.90 & 1.19 & 107.0 & 145.0 & 60.00 \\
\hline Mean & & & 0.43 & 0.58 & 0.24 & 21.40 & 29.00 & 12.00 \\
\hline Megarsa Husien & Kurfa & Dawe & 0.25 & 0.25 & 0.13 & 12.50 & 12.50 & 6.50 \\
\hline Hayati Ahimed & Kurfa & Dawe & 0.40 & 0.25 & 0.18 & 20.00 & 12.50 & 9.00 \\
\hline Jafar Sirajo & Kurfa & Dawe & 0.23 & 0.21 & 0.14 & 11.50 & 10.50 & 7.00 \\
\hline Shifaraw tadasa & Kurfa & Dawe & 0.42 & 0.28 & 0.13 & 21.00 & 14.00 & 6.50 \\
\hline Amadin Yusf & Kurfa & Kerso & 0.00 & 0.00 & 0.00 & 0.00 & 0.00 & 0.00 \\
\hline Debebe Makeshe & Kurfa & Kerso & 0.60 & 0.35 & 0.25 & 30.00 & 17.50 & 12.50 \\
\hline Total & & & 1.90 & 1.34 & 0.83 & 95.00 & 67.00 & 41.50 \\
\hline Mean & & & 0.38 & 0.27 & 0.17 & 19.00 & 13.40 & 8.30 \\
\hline
\end{tabular}

*Indicated that the farmer' demonstration field was attacked by drought

Table 6.5. Summary of agronomic data of common bean varieties in the two districts during Belg season

\begin{tabular}{|c|c|c|c|c|}
\hline \multirow[b]{2}{*}{ Agronomic Data } & \multicolumn{3}{|c|}{ Common beans Varieties } & \multirow[b]{2}{*}{ Remark } \\
\hline & Chercher & Dursitu & Local & \\
\hline Date of planting & Late April & Late April & Same & Rainfall delay \\
\hline Maturity date & End June & End of June & End of June & - \\
\hline Resistance to diseases & high & average & low & - \\
\hline Resistance to drought & High & average & low & - \\
\hline Harvesting Date & End June & Early July & Early July & - \\
\hline Colour & white & brown & mixed & - \\
\hline Market Demand & High & Average & low & - \\
\hline Average yield & 17.9 & 13.5 & 7.9 & - \\
\hline
\end{tabular}

Table 6.6. Summary of agronomic data of common bean varieties in the two districts during Maher Season

\begin{tabular}{|c|c|c|c|c|}
\hline \multirow{2}{*}{ Agronomic Data } & \multicolumn{3}{|c|}{ Common Beans Varieties } & \multirow{2}{*}{ Remark } \\
\hline & Chercher & Haramaya & Local & \\
\hline Date of planting & Late July & Same & Same & Rainfall delay \\
\hline Maturity date & Mid-Oct. & End Oct. & Late Oct. & \\
\hline Resistance to diseases & High & Average & Low & \\
\hline Resistance to drought & High & Average & Low & \\
\hline Harvesting Date & End Oct & Early Nov. & Early Nov. & \\
\hline Colour & White & Brown & Mixed & \\
\hline Market Demand & High & Average & Low & \\
\hline Average yield & 20.2 & 21.2 & 10.2 & \\
\hline
\end{tabular}

Table 6.3 shows that the highest mean yield/ha was recorded in kurfa chele during the Belg season by Chercher improved common bean (19.5qt/ha) which was followed by Dursitu (14.5qt/ha) and the local variety $(9.7 \mathrm{qt} / \mathrm{ha})$, respectively and the order was similar in Gurawa district, but there was yield difference between the districts.

Table 6.4 shows that the highest mean yield/ha was recorded in Gurawa during the Maher season by
Dursitu variety (29 qt/ha) which was followed by Chercher variety (21.4 qt/ha) and the local variety (12 $\mathrm{qt} / \mathrm{ha}$ ). But, the highest mean yield/ha was obtained from Chercher variety (19 qt/ha) in Kurfa chele district which was followed by Dursitu (13.40 qt/ha) and the local variety $(8.3 \mathrm{qt} / \mathrm{ha})$ during the same season. The mean yield differences were due to the inconsistency in rainfall in both districts during the growing seasons. 
Table 6.7. Farmers' selection criteria and responses' to the packages

\begin{tabular}{llcl}
\hline \multirow{2}{*}{ Parameters } & \multicolumn{2}{l}{$\begin{array}{l}\text { Farmers' } \\
\text { common bean cultivars vs local }\end{array}$} \\
\cline { 2 - 4 } & Dursitu & Chercher & Local \\
\hline $\begin{array}{l}\text { Yield } \\
\text { Date of } \\
\text { Maturity }\end{array}$ & High & V. high & Low \\
$\begin{array}{l}\text { Drought } \\
\text { Résistance }\end{array}$ & Medium & High & Low \\
$\begin{array}{l}\text { Diseases } \\
\text { Resistance } \\
\text { Colours } \\
\begin{array}{l}\text { Market } \\
\text { demand }\end{array}\end{array}$ & High & V. high & V.low \\
$\begin{array}{l}\text { Farmers } \\
\text { Rank }\end{array}$ & High & Excellent & Mixed \\
\hline
\end{tabular}

\subsection{Farmers Decision}

Target farmers have decided to grow the two improved common bean varieties and share the available seed to other follower farmers who eagerly follow the demonstration activities.

\section{Conclusion}

Common bean is becoming increasingly important in eastern Ethiopia because of the recurrent late-onset and early termination of rainfall, which force the farmers to use short-duration crops. It is an important component of crop production in Hararghe under various intercropping systems. The major problems of common bean production in Eastern Ethiopia are inaccessibility to improved common bean varieties, low extension intervention, and inferior performance of local varieties.

Eleven improved common bean varieties along with its improved practices during the last 10-15 years, of which eleven are food beans (Gofta, Ayenew, Haramaya, Dursitu and Kufanzik, Tinike, Hirna, Babile, Fedis, Hundane and one navy (white) variety (Chercher) to address these constraints. Among those two improved common bean varieties were compared with the local and both improved common bean varieties (Chercher and Dursitu) met the farmers' criteria. The variety that can be suitable for Belg and Maher seasons were also identified. Chercher variety is suitable for Belg season since it is early maturing and Dursitu variety for the Maher as it is relatively late maturing. Depending on rainfall requirement, yield potential and other quality attributes, however, Chercher variety was selected first by farmers'. This variety has high market demand, shorter maturity date and it is drought tolerant. It was learnt that a demonstration of new technology using appropriate extension methods such as training and farmers' days are among the best approaches in technology transfer. Experiences were shared among target farmers, followers, researchers, agricultural development agents, and other stakeholders through group discussion on the specific improved practices during the farmers' days.

In general, participants' capability and skill on the improved common bean production technologies increased and thereby their common bean production increased from $8.0 \mathrm{qts} / \mathrm{ha}$ to $20.70 \mathrm{qts} / \mathrm{ha}$ as a result of the demonstration made on the two common beans technologies along with training and farmers days. The ground for further popularization and dissemination of the two improved common bean technologies was established.

\section{Acknowledgment}

The financial assistance from Haramaya University for the research worker is highly acknowledged. The authors also wish to thank the Office of the Vice President for Research Affairs of the University for its Invaluable Support.

\section{References}

[1]. Bulti, T. 2007. Yield and Canning Quality Attributes of Navy Beans (Phaseolus vulgaris L.), MSc Thesis, Haramaya University.

[2]. CIAT Bean Improvement website:ciatbean@cgir.org

[3]. Genchev, D., P. Christova, I. Kiryakov, M. Beleva and R. Batchvarova. 2010. Breeding of common bean for resistance to the physiological races of anthracnose identified in Bulgaria. Biotechnol. \& Biotechnol. Eq., 24(2): 1814-1823.

[4]. Hernández-Delgado, S., M.H. Reyes-Valdés, R. Rosales-Serna and N. Mayek -Pérez. 2009. Molecular markers associated with resistance to Macrophomina phaseolina (Tassi) Goid. in common bean. Journal of Plant Pathology, 91 (1): 163-170.

[5]. Kelly, J.D and P.N. Miklas. 1999. MarkerAssisted Selection, pp. 93-132. In: Singh, S.P. (ed.) Common Bean Improvement in the Twenty-First Century. Vol.7. Kluwer Academic Publishers, Dordrecht, Boston, London.

\section{Acronyms}

$\begin{array}{ll}\text { ha } & \text { Hektar } \\ \text { qts } & \text { Quintals } \\ \text { qts/ha } & \text { Quintal per hektar }\end{array}$

